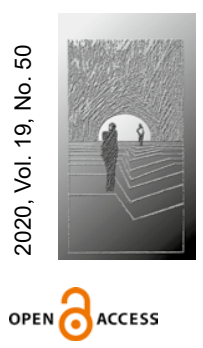

Beata Bednarczuk

http://orcid.org/0000-0002-6564-9199 Uniwersytet Marii Curie-Skłodowskiej w Lublinie Wydział Pedagogiki i Psychologii Instytut Pedagogiki, Katedra Dydaktyki beata.bednarczuk@poczta.umcs.lublin.pl DOI: $10.35765 / \mathrm{hw} .1825$

\title{
Kategoria osoby jako punkt krytyczny rozważań nad wychowaniem. Inspiracje z nurtu personalizmu chrześcijańskiego
}

\section{STRESZCZENIE}

CEL NAUKOWY: Celem niniejszego artykułu jest przywołanie konstytutywnych kryteriów personalistycznej koncepcji osoby jako punktów krytycznych w rozważaniach nad wychowaniem oraz odszukanie i wskazanie inspiracji, a w konsekwencji rekomendacji w odniesieniu do procesu wychowania.

PROBLEM I METODY BADAWCZE: Podstawą zebrania materiału empirycznego jest analiza treści, która zmierza do charakterystyki dotychczasowego dorobku w obrębie wybranego tematu i kierunków prowadzonych dyskusji. Towarzyszą temu elementy interpretacji i konceptualizacji. Postępowaniem badacza kierują reguły metodologiczne, związane z potrzebą zapewnienia sprawdzalności, wiarygodności oraz wartości poznawczej wyników pracy

PROCES WYWODU: Odwołując się do założeń przedstawicieli personalizmu chrześcijańskiego, wskazano sposób interpretacji właściwości osoby, która pełnię rozwoju i własnego istnienia osiąga, działając na rzecz innych i pośród innych ludzi. Zaznaczono, że godność osoby ludzkiej jest podstawą powinności moralnej, a bezwarunkowe respektowanie godności pozwala traktować wychowanie jako służbę na rzecz rozwoju człowieka. Obowiązkiem pedagoga jest dysponowanie dojrzałym systemem wartości i organizowanie sytuacji służących ich rozpoznawaniu. Wybór wartości jest bowiem decydujący w procesie stawania się osobą (lub anty-osobą). Poznawanie i praktykowanie wartości dokonuje się za sprawą spotkania/relacji.

WYNIKI ANALIZY NAUKOWEJ: Przeniesienie założeń personalizmu na grunt pedagogiczny skutkuje przyjęciem założenia, że to człowiek jest programem wychowania. Człowiek charakteryzuje się specyficznymi właściwościami osobowymi, predyspozycjami ku rozwojowi, a wychowanie tworzy warunki do ujawniania i rozwijania wspomnianych potencji w dialogu i interakcji z innymi. Zasadą budowania wzajemnych relacji jest miłość.

WNIOSKI, INNOWACJE, REKOMENDACJE: Ponieważ osoba jest wartością najwyższą, staje się per se, to jej celem jest doskonalenie siebie. W prowadzeniu tej całożyciowej pracy wspomaga proces wychowania. Podczas gdy wychowanie we współczesnej szkole sprowadza się na ogół do działań przystosowawczych do obowiązujących struktur i instytucjonalnych modeli życia, z perspektywy personalizmu jest pomocą udzielaną człowiekowi w odnalezieniu potencjału 


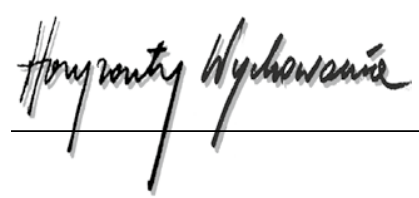

w sobie i wartości wokół siebie, dzięki którym będzie on mógł uczestniczyć w procesie budowania i rozwijania siebie.

\title{
$\rightarrow$ SŁOWA KLUCZOWE: PERSONALISTYCZNA KONCEPCJA CZŁOWIEKA, CECHY WYCHOWANIA PERSONALISTYCZNEGO
}

\begin{abstract}
The Category of a Person as a Critical Point in Considering the Process of Upbringing. Inspirations from the Christian Personalism
\end{abstract}

RESEARCH OBJECTIVE: This article aims to recall the constitutive criteria of the personalistic conception of a person as critical points in considerations on upbringing and to find and indicate inspiration and, consequently, recommendations for the upbringing process.

THE RESEARCH PROBLEM AND METHODS: The basis for collecting empirical material is the analysis of the content, which aims to characterize the achievements within the selected topic and directions of discussions. It is accompanied by elements of interpretation and conceptualization. The conduct of the researcher is guided by methodological rules related to the need to ensure the verifiability, credibility, and cognitive value of the work results

THE PROCESS OF ARGUMENTATION: Referring to the assumptions of the representatives of Christian personalism, the method of interpreting the qualities of a person who achieves full development and his own existence by acting for the benefit of others and among other people was indicated. It was emphasized that the dignity of the human person is the basis of moral duty and that unconditional respect for dignity allows for treating the process of upbringing as a service for human development. The educator has to have a mature system of values and organize situations that help to recognize them. The choice of value is decisive in the process of becoming a person (or anti-person). Learning and practicing values takes place through a meeting/relationship.

RESEARCH RESULTS: Transferring the assumptions of personalism to the pedagogical ground results in the assumption that human is the program of education. Man is characterized by specific personal qualities, predispositions towards development, and upbringing creates conditions for revealing and developing the aforementioned potentials in dialogue and interaction with others. The core principle of building mutual relations is love.

CONCLUSIONS, INNOVATIONS, AND RECOMMENDATIONS: Since a person is the highest value, he/she becomes per se, his/her goal is to perfect himself. In carrying out this lifelong work, he/she is supported by the upbringing process. While upbringing in a modern school usually boils down to adapting to the existing structures and institutional models of life, from the perspective of personalism, it is the help given to a person in finding their potential and values around them, thanks to which he/she will be able to participate in the process of building and developing himself.

\section{$\rightarrow$ KEYWORDS: PERSONALISTIC CONCEPT OF MAN, FEATURES} OF PERSONALISTIC PROCESS OF UPBRINGING 
Procesy kształcenia i wychowania opierają się, co wskazuje Krystyna Ostrowska (2005), na pełnym, wolnym rozwoju każdego człowieka, w takich granicach, w jakich jest tylko możliwe, przy uwzględnieniu istniejących warunków indywidualnych, społecznych i gospodarczych. Przyjęcia rozwoju dziecka/ stającego się człowieka za najwyższą wartość procesów edukacyjnych prowadzi do wniosku, że system szkolny i działalność pedagogiczna pozostają w służbie tej wartości, a nie odwrotnie (Ostrowska, 2005, s. 293). Pedagogika, ujęta źródłowo, pomimo wielu różnic światopoglądów, idei czy kultur, wymaga oparcia się na wiedzy - przede wszystkim i w pierwszej kolejności o tym, kim jest człowiek. Z powyższego wynika kolejna kwestia: czy potencjalnie ma w sobie coś, z powodu czego zasługuje na szczególne traktowanie? (Łobocki, 2009, s. 23). Pamiętać trzeba, że pedagogika jest autonomiczna przez zakorzenienie w prawdzie o istocie ludzkiej. W związku z tym uczeni wskazują ważką prawdę (Kaczmarek i Gadacz, 2005, s. 172-173) - zanim ktoś się stanie dzieckiem jakiejkolwiek cywilizacji, jest dzieckiem człowieczym, człowiekiem, osobą. Wskazana prawda stanowi nieprzekraczalny horyzont człowieczeństwa (Kaczmarek i Gadacz, 2005). Celem niniejszego artykułu jest zatem przywołanie konstytutywnych kryteriów personalistycznej koncepcji osoby jako punktów krytycznych w rozważaniach nad wychowaniem oraz odszukanie i wskazanie inspiracji, a w konsekwencji rekomendacji w odniesieniu do procesu wychowania.

Podstawą zebrania materiału empirycznego jest analiza treści, opisywana jako proces eksploracyjny, skutkujący odczytaniem znaczeń. Krytyczna analiza treści prowadzi do możliwie systematycznego i rzetelnego wskazania, jakie tematy oraz w jaki sposób były poruszane w zebranym materiale badawczym (Szczepaniak, 2012, s. 84-86). Przyjmuje się, że celem metody analizy i krytyki treści tekstów jest przede wszystkim charakterystyka dotychczasowego dorobku w obrębie wybranego obszaru tematycznego czy kierunków prowadzonych dyskusji. Towarzyszą temu elementy interpretacji i konceptualizacji. Postępowaniem badacza kierują reguły metodologiczne, związane z potrzebą zapewnienia sprawdzalności, wiarygodności oraz wartości poznawczej wyników pracy (Cisek, 2010, s. 277-280).

\section{Personalistyczny wymiar osoby}

Personalizm chrześcijański w centrum swoich zainteresowań stawia pełny i integralny rozwój osoby ludzkiej. Osoba ludzka, wyjaśnia Mieczysław Albert Krąpiec (1999), jest wyjątkowym i jednostkowym bytem osobowym, dominującym nad całą naturą. Istnieje jako byt dynamiczny, rozwijający się powoli i zyskujący doskonałość na drodze reorganizacji danego sobie potencjału. Podkreślona przez autora dynamika osoby wynikająca z potencjalności ludzkiego życia - „ogarniająca wszystkie aspekty realne całej ludzkiej bytowości, stanowi istotny wymiar tego życia” (Krąpiec, 1999, s. 82), albowiem człowiek spełnia się właśnie poprzez aktualizację owych potencji. Z kolei Stanisław Chrobaka zauważa, że 


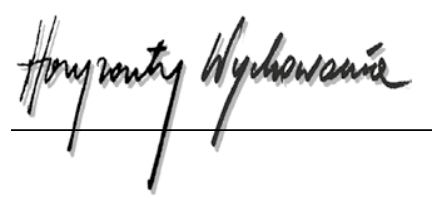

potencjalność oznacza z jednej strony niesamodzielność i potrzebę współdziałania, a z drugiej możliwość rozwoju. Człowiek dobiera swoje akty, przez które wyraża się i ingeruje w świat zastany. Odpowiednie dobieranie sobie aktów (...), jest właśnie tworzeniem osobistej natury, konstruowaniem osobowej „twarzy” (Chrobak, 2009, s. 274-275).

Mechanizmem aktualizowania potencjalności staje się transcendowanie (Rzechowska, 1995, s. 35).

Drugi immanentny wymiar ludzkiego bytu w interpretacji M.A. Krąpca (1999) ma charakter społeczny, co oznacza, że człowiek może się rozwijać tylko pośród i dla ludzi. „Istotą osoby jest bowiem istnienie samej w sobie, choć zarazem w dialektycznej relacji do innych osób" (Góźdź, 2008, s. 409). Obecność drugiego człowieka nadaje rozwojowi właściwy sens. Stąd też można, za Adolfem Szołtyskiem, wskazać wielopłaszczyznową perspektywę interpretacyjną istnienia i rozwoju człowieka.

Zaistniały Ja-człowiek jest metafizyczną trój-jednią, w której da się wyróżnić:

Ja - człowieka jako osobę ludzką, należącą do same siebie;

Ja - człowieka jako istotę społeczną, należącą do danej wspólnoty;

Ja - człowieka jako obywatela, należącego do danego państwa (Szołtysek, 1999, s. 21).

Marian Nowak (2003, s. 235) podkreśla, że stawanie się osoby, narodziny nowego człowieka na drodze wydobywania w procesie rozwoju tego, co potencjalnie istniało, doskonalenie i budowanie istoty ludzkiej dokonuje się w niej samej, ale zawsze wobec kogoś i czegoś, w konkretnej sytuacji, w określonym czasie, w społeczności osób i we wspólnocie z nimi. W ten sposób, zgodnie z sugestią M. Nowaka, nieodzowne wydaje się wyjaśnienie kolejnego konstytutywnego dla organizacji procesu wychowania pojęcia: wspólnota. Badacz definiuje ją następująco: Wspólnota

\begin{abstract}
powstaje jako fenomen szczególnych relacji międzyludzkich - „z serca do serca”, „od osoby do osoby" - w których nie można mówić o organizacji (...). Wspólnota jest pojęciem podkreślającym relację (jest to byt w relacji), (...) powstaje ze względu na dobro osób i ma ona wartość w sobie samej (Nowak, 2003, s. 235).
\end{abstract}

Zgodnie z zarysowaną koncepcją, społeczność jest zbiorowością osób, powstałą z motywów racjonalnych dla osiągnięcia jakiegoś celu, leżącego poza ową społecznością (Nowak, 2003). Z kolei uczestnictwo osób we wspólnocie powoduje zrodzenie się idei solidarności, obejmującej „Ja” i „Ty”, wzbudzanie osoby, wsparcie formowania siebie. Personalizm uznaje wartość dobra wspólnego za podstawę życia społecznego, niemniej nie może ono naruszać dobra człowieka rozumianego jako osobę.

Sensem życia społecznego jest bowiem wszechstronny rozwój osoby ludzkiej, nad którą nie może być wyższych celów, z powodu których (rzekomo) mogłaby być ona traktowana jako środek. Osoba jest zawsze celem (Nowak, 2003, s. 244). 
Czesław Bartnik (2013) zauważa, że nie można oddzielić osoby i społeczności, gdyż jedna jest warunkowana przez drugą. Być osobą, uzasadnia autor, to być doskonale i w pełni dla innych i w ten sposób realizować nieskończenie siebie samego. Jednakże nie ma społeczności bez jednostki i nie ma osoby bez społeczności. Osoba - podkreśla uczony - jest niepowtarzalna, niepodzielna, jedyna, a konstytuuje ją to, że istnieje przez innych i dla innych (Bartnik, 2013, s. 218).

Reasumując, człowiek jest osobą, niepowtarzalnym bytem, który pełnię rozwoju i własnego istnienia osiąga, działając na rzecz innych i pośród innych ludzi. Jest to podstawowa zasada organizowania działań wychowawczych, których podmiotem oraz celem jest osoba. Tadeusz Gadacz (1997, s. 21) wskazuje, że dotyczy to zarówno osoby wychowanka, jak i osoby wychowującej.

\section{Godność osoby fundamentem wychowania}

Podstawowym wymiarem człowieka i jego człowieczeństwa jest godność. Ma ona swoją podstawę w ontycznej strukturze człowieka. Jest „w pewnym sensie wyznacznikiem moralnej wartości ludzkiego działania” (Jan Paweł II, za: Bagrowicz, 1999, s. 107) i fundamentalną wartością całego porządku moralnego. Co więcej, stanowi „normę personalistyczną" (Nowak, 1990, s. 320). Papież Jan Paweł II, rozważając prawa człowieka, wskazuje, że znajdują one swój fundament właśnie w godności człowieka. Stąd też całokształt prawodawstwa winien odpowiadać istocie godności osoby ludzkiej (za: Nowak, 1990, s. 108). W tym rozumieniu jądrem godności, ale i czymś, co przysługuje człowiekowi, stają się: prawo do życia i rozwoju biologicznego, prawo do życia i rozwoju duchowego, prawo do wolności w ogóle, a do wolności religijnej w szczególności, prawo do życia małżeńskiego i rodzinnego, prawo do dóbr gospodarczych i uczestnictwa w życiu społeczno-politycznym (Nowak, 1990). Przez godność można rozumieć stan uznawania wartości człowieka, i to zarówno w podstawowym sensie, tj. związanym z naturą ludzką, jak i w rozumieniu szerszym, uwzględniającym zależność od zachowań i sytuacji (Jankowska, 2011, s. 205). Stąd, na gruncie psychologii, godność utożsamiana jest z poczuciem własnej wartości (Jankowska, 2011). I tak np. Józef Kozielecki (1988, s. 10) formułuje wniosek, iż godność jest trwałym przekonaniem jednostki o jej autentycznej wartości jako człowieka będącego niepodzielną całością. Jest ona moralnym składnikiem osobowości każdego człowieka, jak również ważnym wymiarem człowieczeństwa.

Z uznania godności osoby jako celu samego w sobie wynika prawda, że człowiek nie może być dla nikogo narzędziem osiągania jakiegoś dobra, lecz sam stanowi cel, któremu powinien służyć świat rzeczy (Granat, za: Bagrowicz, 2005, s. 185). Godność osoby ludzkiej jest podstawą powinności moralnej i wymaga uznania oraz respektowania jej nie dlatego, że dana osoba jest ważna czy znacząca, lecz z racji samej właśnie godności. Wartości człowieka musi odpowiadać intencja oddziaływań pedagogicznych, o czym będzie mowa w dalszej części artykułu. 


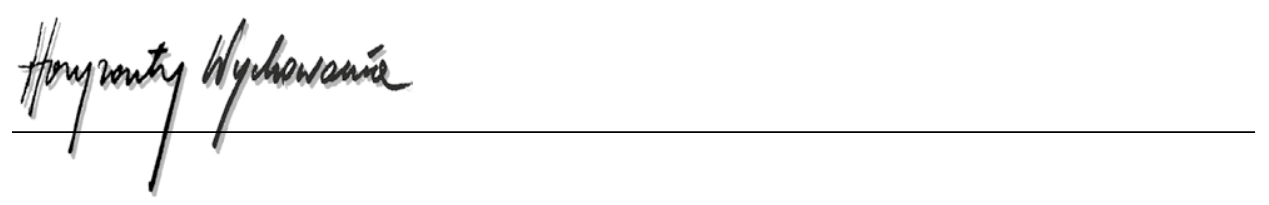

\section{Wychowanie wobec godności osoby}

„Odpowiedzią osobową" na wartość człowieka jest wychowanie nastawione na integralny rozwój osoby. Warto w tym miejscu przypomnieć, że jeśli nawet orientacji personalistycznej nie towarzyszy refleksja źródłowa, ukazująca religijne korzenie charakteryzowanego sposobu myślenia (przynosząca uzasadnienie bezwarunkowej godności człowieka), to i tak pozwala ono traktować człowieka jako w pełni zintegrowaną całość, psychofizyczno-duchową istotę, której sens istnienia jest daleko wyższy niż tylko osiąganie przyjemności (Olbrycht, 1999, s. 15). Zatem, treścią życia i wychowania staje się służba na rzecz człowieka (Bagrowicz, 1999), urzeczywistnianie człowieczeństwa (Nowak, 2005, s. 246), a także wspieranie rozwoju człowieka zdolnego do podejmowania samodzielnych i odpowiedzialnych decyzji (Twardowski, za: Ostrowska, 2005, s. 291-292). Dokonuje się to poprzez kształtowanie cech i sprawności, które umożliwiają zarówno budowanie złożonego obrazu kultury w każdym człowieku, jak i aktualizowanie niepowtarzalnej struktury osobowej (Mounier, za: Nowak, 2003, s. 243; zob. też Bagrowicz, 2008, s. 356-359).

Przyjęcie wspomnianych założeń prowadzi do wniosku, że proces wychowania opiera się na „rozpoznaniu (...), unaocznianiu (...) godności osobowej, naprowadzaniu na tę wartość” (Chudy, 2009, s. 59), na wzajemnym poważaniu, atencji w odnoszeniu się do innych (Chudy, 2009), a podstawową zasadą oddziaływań wychowawczych jest zasada miłości - afirmacji osoby (Grzywak-Kaczyńska, 2005; Nowak, 1999, s. 475-483). Wychowanie w związku z tym jest powodowaniem i utrwalaniem więzi osobowych łączących osoby. Podstawową jest miłość (Gadacz, 1997, s. 25). Akt uznania drugiej osoby obrazuje najszersze rozumienie miłości i wiąże się z „bezinteresownością czynu dobrego moralnie" (Chudy, 2009, s. 121). Człowiekowi jako osobie przynależna jest godność, jest on godzien miłości i może tą miłością dzielić się z innymi (Bagrowicz, 1999, s. 112). Konsekwencją przybliżonego sposobu myślenia jest teza, że wychowanie to po prostu akt miłości wzorowanej na tej, jaką został umiłowany przez Boga każdy człowiek. Miłość polega na czynieniu dobra, w procesie wychowania łączy się z postawą życzliwości i szacunku, z otwartością oraz akceptacją innego (Olbrycht, 2005, s. 246).

M. Łobocki stawia pytanie, czy kreślona w taki sposób perspektywa interpretacyjna wychowania nie jest nieco wyidealizowana czy wręcz nierealna. Pedagog wyjaśnia jednakże, że uznanie, iż dziecko zawsze zasługuje na poszanowanie swojej godności, nie wyklucza ewidentnego sprzeciwu wobec jego aspołecznych zachowań czy postaw (Łobocki, 2009, s. 26).

\section{Odkrywanie i wybór wartości źródłem rozwoju}

Ranga godności osoby, w kontekście rozważań o edukacji, skłania do podkreślenia prawa wychowanków do wolnego wyboru, do zadawania pytań, do dyskusji, do poszukiwania i żądania uzasadnień. Nie jest to równoznaczne, wyjaśnia Zofia Matulka (2005), 
ze zgodą na brak respektowania wymagań szkoły. K. Olbrycht precyzuje pojęcie wymagań z perspektywy myśli personalistycznej:

Zasadniczego znaczenia nabiera odpowiedź na pytanie, czy dziecko ma prawo do braku wymagań, czy też właśnie do wymagań stymulujących rozwój, na co wskazują wyniki psychologii rozwojowej. Stoimy na stanowisku, iż podstawą rozwoju są zadania dynamizujące wielostronną aktywność człowieka. Ich programowe konstruowanie, porządkowanie, pozytywnie motywujące do ich podejmowania podsuwanie, wspieranie w ich rozwiązywaniu - to działania stanowiące istotę wychowania i wszelkiego działania pedagogicznego (Olbrycht, 2005, s. 243).

Nie oznacza także, że wychowankom wolno odrzucać ukazywane w procesie kształcenia wartości absolutne, doskonalące osobę, a jednocześnie integrujące ze społeczeństwem. Z. Matulka (2005) tłumaczy:

Właśnie dlatego, wobec tych wartości istnieje powinność ich przyjęcia (...). Proces jednak internalizacji tych wartości przez uczniów ma być rozumny i dobrowolny (Matulka, 2005, s. 231).

Być wychowawcą - tzn. rodzicem, nauczycielem lub pedagogiem - konstatuje K. Ostrowska (2005) - to dysponować mocnym, dojrzałym systemem wartości. Zadaniem pedagogów jest zatem kreowanie sytuacji sprzyjających

kształceniu intelektualnego rozpoznawania wartości, ich nazywania i uczciwego uzasadniania ich miejsca w hierarchii uznanej przez pedagoga za prawdziwą, kształcenie uczuć wyższych dynamizujących realizację wartości coraz wyższych - tym samym, coraz trudniejszych (Olbrycht, 1999, s. 17).

Zadaniem pedagogów, w ujęciu personalistycznym, jest organizowanie zadań i sytuacji wychowawczych na rzecz kształcenia umiejętności

intelektualnego rozpoznawania wartości, ich nazywania i uczciwego uzasadniania ich miejsca w hierarchii uznanej przez pedagoga za prawdziwą, kształcenie uczuć wyższych dynamizujących realizację wartości coraz wyższych - tym samym, coraz trudniejszych (OIbrycht, 1999, s. 17).

Organizowanie wartości, zdaniem przywoływanego tu J. Majki, stanowi próbę takiego ich przybliżenia, aby stały się łatwe do internalizacji przez wychowanka. Z jego strony wymaga to jednak wysiłku polegającego na wyborze wartości oraz podjęciu takich działań, aby zobiektywizowane wartości zostały zidentyfikowane i zinterpretowane zarówno przez osobę, jak i w osobie, dokonując jednocześnie jej przemiany. W ten oto sposób wartości wzbogacają osobę, umożliwiają reprodukowanie ich i przejmowanie przez innych (Majka, 2005, s. 157).

Dowiedziono, że człowiek żyje w kręgu wartości, wobec których musi się samookreślić: jedne wybiera, inne pomija. Wówczas odkrywa własną wolność, źródło stawania się 


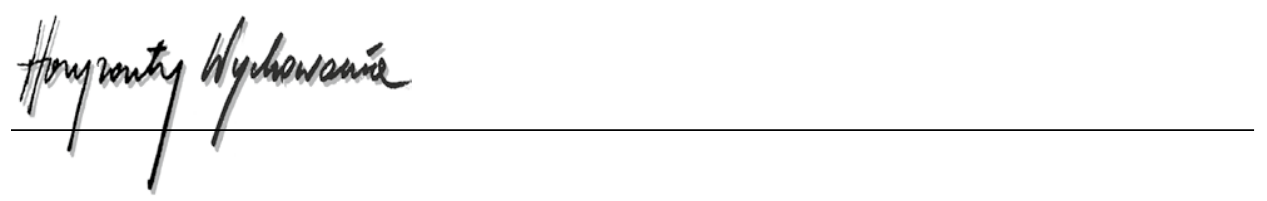

człowiekiem - dobrym lub złym - przez swoje czyny. Subiektywne przeżycie wolności wyraża się w postawach człowieka, określanych w następujący sposób: „mogę - nie muszę - chcę" (Kowalczyk, 2008). Oznacza to, że własną motywację do rozwoju wychowanek realizuje przez niezależne wybory/decyzje. Podjęcie decyzji wymaga wiedzy, wolności i odpowiedzialności.

Wiedza zdobywana przez człowieka powinna stwarzać szanse na udzielenie odpowiedzi na trzy podstawowe pytania: Czym jest świat? Kim jest człowiek? Kim jestem ja jako człowiek żyjący w tym świecie? Brak uproszczonych chociażby reakcji na tak postawione pytania uniemożliwia sporządzenie modelu przyszłości, niezbędnego do sformułowania rozwojowych zadań dalekich. Posiadanie wiedzy, na podstawie której można sformułować odpowiedzi na wskazane trzy pytania, jest równoznaczne z posiadaniem „wiedzy uniwersalnej”. Psycholog wyróżnia także „wiedzę jałową”, zdobytą dla samej wiedzy, bez określonego przeznaczenia, na zasadzie „trzech Z”, która to wiedza leży u podstaw programów szkolnych (Obuchowski, 1985, s. 235-243).

Z kolei „wiedza podmiotowa”, system wartości, światopogląd wyznaczają wolność wewnętrzną, zaś warunki zewnętrzne dla podmiotu, obecne w jego świecie, wyznaczają wolność zewnętrzną/działania (Czerepaniak-Walczak, 2006, s. 70). „Warunek wolności zewnętrznej jest podyktowany wolnością wewnętrzną, potrzebą wielostronnego rozwoju, która wymaga jej dla realizacji w życiu społecznym" (Chapliy, 2013, s. 94). Akt wolnego wyboru kształtuje osobę oraz jej relacje ze światem. M. Czerepaniak-Walczak przywołuje pomocną kategorię „wolności do”, wyrażającą się „w świadomości siebie jako istoty myślącej, ponoszącej odpowiedzialność za wybory, których się dokonuje i potrafiącej wyjaśnić je w odniesieniu do własnych idei i zamierzeń” (Berlin, za: Czerepaniak-Walczak, 2006, s. 19). Tak interpretowana wolność, zdaniem badaczki, sprzyja uzgadnianiu miejsca i zakresu działania w środowisku społecznym. Człowiek bowiem jest prawdziwie wolny dopiero wówczas, gdy szanuje wolność innych, co oznacza podejmowanie działań odpowiedzialnych. Natomiast osoba staje się w pełni odpowiedzialna za swoje decyzje i czyny, gdy postępuje na mocy własnego wyboru, w sposób możliwie wolny od zewnętrznych nacisków (Łobocki, 2009, s. 75).

\section{Wychowawcze znaczenie wolności}

Sytuowanie na czele hierarchii wartości wolności oraz dążenie do jej osiągniecia to efekt spełnienia wielu warunków. Przede wszystkim autodyscypliny, osiągnięcia dojrzałości, ale i ogromnego wysiłku, związanego z rozpoznaniem wartości, przekształceniem jej w sobie, identyfikacji z wartością, wzbogaceniem osoby, przekazaniem wartości innym (Majka, 2005, s. 157). Właściwie pojęta wolność jest równoznaczna z możliwością wyrażenia osobowej istoty, podjęciem decyzji woli wobec konkretnych wyzwań (Nowak, 2005, s. 349). Wolnością nie jest zatem swawola, tłumaczy J. Majka (2005, s. 159), lecz jest nią zdolność do wyboru dobra i jego realizacja, poszukiwanie wartości, które poznaliśmy i uznaliśmy za godne naszych starań. Wolność jest także środkiem służącym 
doskonaleniu osobowemu. Ponadto, wolność nierozerwalnie połączona jest z odpowiedzialnością. Obie cechy wzajemnie się warunkują, występują jako „nieodłącznie związane z myśleniem i działaniem w pedagogice" (Nowak, 2005, s. 345). Być wolnym, to podejmować samodzielnie decyzje oraz przyjmować odpowiedzialność przed kimś, za coś i za kogoś. Z akceptacji tej postawy jasno wynika, że człowiek jest odpowiedzialny za swoje życie, zwłaszcza w tym zakresie, aby je zrealizować na miarę swojego istnienia i swojej istoty. Pozostaje także odpowiedzialny za życie innych, albowiem realizuje siebie tylko w relacjach społecznych (Nowak, 2005, s. 350).

\section{Wychowanie jako spotkanie osób}

Sytuacje wychowawcze, jak zostało wskazane, wymagają ukazania całego systemu wartości, umożliwienia wyboru, po ich poprzednim poznaniu i zrozumieniu (Chrobak, 2009, s. 432). Poznawanie i praktykowanie wartości dokonuje się za sprawą spotkania, relacji interpersonalnych, zaangażowania w kontekście wspólnotowym, podczas spotkania, za sprawą dialogu. Zachodzi wówczas operacjonalizacja przywołanej wcześniej „normy personalistycznej” (Bagrowicz, 2008). Wychowanie przyjmuje postać szczególnego rodzaju relacji międzyludzkich, w których podmiotem i przedmiotem czynów wychowujących jest osoba (Nowak, 1999, s, 320). Jako podmiot wychowanek jest bytem istniejącym i działającym w sposób autonomiczny. Jako przedmiot pozostaje wyłącznie w relacji zależności do innego podmiotu (Łobocki, 2009).

Spotkanie jest wyrazem otwartości w relacjach interpersonalnych ,ja-ty”, ,ja-wy” (Rusiecki, 2008, s. 434), czyli szeroko pojętym obustronnym otwarciem na dawanie i otrzymywanie. Zaznaczyć przy tym trzeba, że doskonałość osoby pogłębia się przez dawanie (Majka, 2005, s. 157). Spotkanie wiąże się z dwoistością ról w relacji pedagogicznej, albowiem nauczyciel staje się w niej także uczniem, a uczeń w pewnym sensie przyjmuje rolę nauczyciela (Jan Paweł II, za: Chudy, 2009, s. 209-210). W przebiegu relacji wychowawczej spotkanie odzwierciedla współdziałanie i współdoznawanie. Jest to specyficzna relacja dialogiczna (Molesztak, 2009, s. 259). Wychowanie opisywane z perspektywy personalistycznej definiowane jest także jako „samowychowanie w dialogu”. Trzeba również dodać, że „przestrzeń” dialogu wychowawczego stanowią nie tylko osoby zaangażowane w rozmowę, ale również pewne warunki i określone zasady, bez zaistnienia których dialog w koncepcji personalistycznej przestaje być zwyczajną rozmową. Do podstawowych warunków dialogu zalicza się autentyczność, prawdę, otwartość na wspólnotę osób oraz bezinteresowność (wzajemną pomoc w autokreacji) (Szudra, 2009, s. 214-223). Ważnym kryterium zaistnienia dialogu jest również odkrywanie siebie poprzez zadawane pytania. „Kierując swe pytanie do mnie, dając tym samym wyraz swemu odkryciu mnie, inny człowiek oczekuje, że i ja - przynajmniej częściowo - odkryję się przed nim" (Tischner, za: Walczak, 2009, s. 234, zob. też Śnieżyński, 2009).

Spotkanie można potraktować jako swoiste narzędzie wspomagające rozwój człowieka w kontakcie z innymi ludźmi, z wartościami kultury, wiedzy oraz religii. Jego 


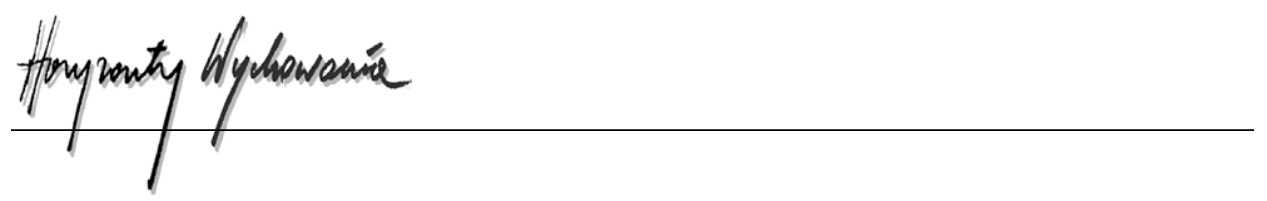

funkcją jest przygotowanie osoby do życia w rozmaitych społecznościach. Metaforycznie można powiedzieć, że spotkanie mistrza i ucznia jest miejscem wychowania (Kaczmarek i Gadacz, 2005, s. 177). Rozszerzając za Markiem Styczyńskim (2009, s. 211) metaforę miejsca, chodzi tu o spotkanie, w szerokim tego słowa znaczeniu, z innymi ludźmi, z sobą samym, ze światem, z wartościami, tradycjami, znaczeniami, które stają się platformą dla procesu komunikacji. Przestrzeń szkoły jawi się wówczas jako wspólnota osób, w której „każdy i wszyscy” mogą uczestniczyć w realizacji danego sobie potencjału (Chudy, 2009, s. 211). Dlatego instytucje edukacyjne czy wychowawcy nie kształtują osoby, ale ją „wzbudzają”, kreują warunki jej rozwoju, czy też rozwój ten bezpośrednio umożliwiają (Majka, 2005). Proces doskonalenia i kształtowania się osoby musi być owocem jej własnych wysiłków. Wychowawca pełni funkcję współpracownika w tym dziele, przygotowuje wychowanka do przejęcia kierownictwa nad przebiegiem indywidualnego wzrostu (Nowak, za: Bagrowicz, 2005, s. 206, zob. też Kunowski, 2000; Śliwerski, 2003).

\section{Znaczenie założeń personalizmu dla procesu wychowania}

Przeniesienie założeń personalizmu na grunt pedagogiczny skutkuje, w analizach Jarosława Horowskiego (2011), kilkoma ważkimi tezami. Ich analizę warto poprzedzić uwagą, że instytucje wychowawcze czy wychowawcy nie kształtują osoby, ale ją „wzbudzają", kreując warunki na rzecz jej rozwoju. Proces rozwoju i doskonalenia się osoby jest owocem jej własnego wysiłku. Wychowawca odgrywa rolę współpracownika w tym dziele, przygotowuje wychowanka do przejęcia kierownictwa nad przebiegiem indywidualnego wzrostu. Stąd, jeśli wychowanie w optyce instytucjonalnej związane jest z zewnętrznymi wobec dziecka przepisami i programami, w optyce personalistycznej programem jest sam człowiek wraz z jego życiem (Gadacz, 2005, s. 220).

Wspomniane tezy dotyczące wychowania dotyczą trzech perspektyw interpretacyjnych osoby: osoba ludzka, istota społeczna, obywatel państwa (Szołtysek, 1999). Ponieważ człowiek jest osobą ludzką, należącą do siebie samej, w wychowaniu personalistycznym podkreślany jest fakt niepowtarzalności osoby oraz jej prawa do wyboru indywidualnej drogi rozwoju i doskonalenia, mając na uwadze wszelkie formy i poziomy kształcenia oraz wychowania (zob. Adamski, 2005, s. 13). To, jaką osobą stanie się wychowanek, zależy wyłącznie od niego samego (Horowski, 2011), od jego wysiłków. Stąd aktywny stosunek wychowanka do przedstawianych w procesie wychowania wartości staje się warunkiem koniecznym dla przebiegu i efektów tego procesu (Adamski, 2005, s. 15). Instytucje wychowawcze tworzą warunki, aby wychowankowie mogli się zetknąć z wartościami wytworzonymi w społeczeństwie, a stanowiącymi jego trwały dorobek. Ponadto, personalizm kreśli wizję człowieka jako osoby, która się staje „dla-osoby-drugiej” (Krąpiec, 2005, s. 40), „transcendentuje swoje uwarunkowania, wychodząc ku innej osobie i angażując się w życie społeczne" (Adamski, 2005, s. 37). Proces wychowania wspiera wychowanka w owej transcendencji, „WY-dobywania-na-jaw-tego-co-CHOWANE” 
(Szołtysek, 1999, s. 27). Z perspektywy unikatowości osoby wychowanie polega na „uzdatnianiu człowieka do pokierowania rozwojem, tak aby odnalazł i urzeczywistniał «najgłębsze ja»" (Tarnowski, za: Śliwerski, 2003, s. 68).

Ponieważ człowiek staje się istotą społeczną, należącą do danej wspólnoty, oraz obywatelem przynależnym do danego państwa, w konsekwencji prowadzi to do wniosku, że wychowanie powinno się opierać na budowaniu relacji, wprowadzaniu do wspólnoty (Szołtysek, 1999; Śnieżyński, 1999; Chrobak, 1999; Gadacz, 2005). Będzie ono wówczas szczególnym rodzajem łączności, ujętym w formie zasady: „właściwym odniesieniem do osoby jest miłowanie jej” (Nowak, 1999, s. 320; zob. też Nowak, 2005). Obszarem zaś, który umożliwia uspójnienie, integrację indywidualnej i społecznej natury osoby, staje się interakcyjność. Jan Tarnowski nazywa tę cechę inter- i intraakcyjnością, mając na uwadze obustronne oddziaływane na siebie podmiotów, wzajemne otwieranie się na swoje wartości (za: Śliwerski, 2003, s. 68), ale także wchodzenie w relację z samym sobą, czyli samowychowanie.

Katalog wymienionych założeń wychowania personalistycznego uzupełnia permanencja, czyli ciągłość procesu w biegu życia człowieka, albowiem potrzeba wychowania, a zatem pełniejszego bycia sobą, doskonalenia siebie nigdy nie zanika. Nie można także zapomnieć o gotowości na nieoczekiwane, na nieokreśloność sytuacji i zdarzeń, co wymaga stałego otwierania się uczestników charakteryzowanego tu procesu na nowość (Tarnowski, za: Śliwerski, 2003, s. 68-69).

Podsumowując dotychczasowe rozważania, człowiek charakteryzuje się specyficznymi właściwościami osobowymi, predyspozycjami ku rozwojowi, a wychowanie tworzy warunki do ujawniania i rozwijania wspomnianych potencji w dialogu/interakcji. Wychowanek jest zdolny do poznawania siebie i pracy nad sobą, a cały wysiłek wychowania samego siebie jest ściśle związany ze sferą woli (Nowak 1999, s. 444-456). Dla tego rodzaju pracy musi zostać podjęta współpraca wychowanka z wychowawcą i otoczeniem (Nowak, 1999, s. 459).

\section{Wnioski}

W personalizmie chrześcijańskim wyróżnia się pewne cechy osoby, które pokazują jej istotę. Należą do nich m.in.: indywidualna natura i społeczny charakter, integralność, samodzielność bycia, samoistna godność. Wartość osoby ludzkiej jest wartością samą w sobie i nie pochodzi z pośrednictwa lub nadania innych, wynika bowiem z samej istoty i natury człowieczeństwa. Osoba jest tutaj wartością najwyższą, staje się per se - jej celem jest doskonalenie siebie. W prowadzeniu tej całożyciowej pracy wspomagać ma proces wychowania.

Wychowanie we współczesnej szkole sprowadza się przede wszystkim do przystosowywania do określonych, obowiązujących struktur i instytucjonalnych modeli życia (Gadacz, 2005, s. 214). Tymczasem wychowanie w swojej istocie to pomoc człowiekowi „w odnalezieniu tych możliwości w sobie i wartości wokół siebie, dzięki którym będzie 


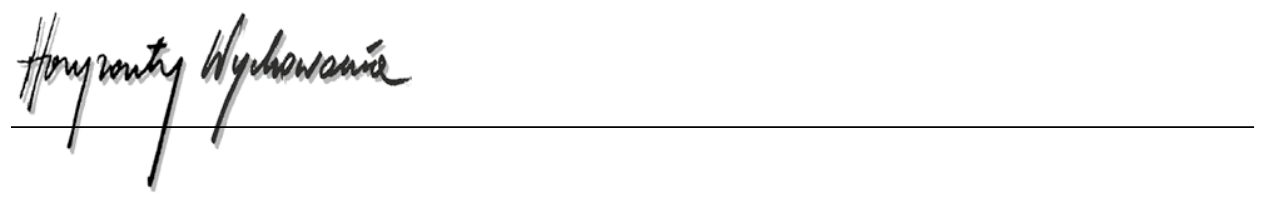

mógł świadomie kierować swoje postawy wobec siebie i świata” (Mróz, 2008, s. 10), w czasie spotkania z drugą osobą. Wychowanie nie sprowadza się do wywierania wpływów wychowawczych z zewnątrz. Obejmuje swoim zasięgiem wpływy wewnętrzne, wyrażające się w bezpośrednim uczestnictwie wychowanków w procesie udoskonalania i rozwijania swej osobowości. Oznacza to, że każdy wychowanek pełni podwójną funkcję: podmiotu i przedmiotu wychowania (Łobocki, 1978, s. 18), staje się „przedmiotem-podmiotem w sobie" (Dąbrowski, 1979). Akt wychowania, będący podstawą autokreacji, dokonuje się w samym wychowanku.

Od strony aksjologicznej człowiek definiowany jest przez wartości, do których należą: odniesienie do wolności (wola), odniesienie do prawdy (rozum), cielesność oraz wartość niejako sumaryczna, nadbudowana na trzech wymienionych, tj. godność (Chudy, 2009, s. 40-43). Wskazane wartości określają specyfikę procesów oświatowych. Niedocenianie wartości prowadzi do wzrostu zjawiska brutalizacji życia, zaniku sacrum na rzecz profanum,

czy po prostu absolutyzacji doczesności, a także różnych innych przejawów patologii społecznej (...). Natomiast przybliżanie dzieciom i młodzieży wartości usensownia z czasem ich życie (Łobocki, 2006, s. 82).

Podobnie twierdzi Cz. Bartnik (2013, s. 298). Stosunek do trzech wartości, tj. prawdy, dobra i piękna decyduje o stawaniu się osobą albo anty-osobą. Człowiek może się sam w sobie realizować, urzeczywistniać, samorealizować przede wszystkim przez wartości prozopoiczne działania: prawdę, dobro i piękno oraz przez cały system wartości, które współokreślają życie osobowe. Jedynie prawda i dobro mogą realnie pokierować mądrością, podstawową zasadą w wychowaniu (Gadacz, 1997, s. 34).

\section{BiBLIOGRAFIA}

Adamski, F. (2005). Wprowadzenie: personalizm - filozoficzny nurt myślenia o człowiek u i wychowaniu. W: F. Adamski (red.), Wychowanie personalistyczne. Wybór tekstów. Kraków: Wydawnictwo WAM.

Bagrowicz, J. (1995). Wychowanie personalistyczne w chrześcijaństwie. W: S. Kowalczyk (red.), Z refleksji nad człowiekiem. Człowiek, społeczność, wartość. Lublin: Towarzystwo Naukowe KUL.

Bagrowicz, J. (1999). Godność osoby fundamentem wychowania. W: F. Adamski, Wychowanie na rozdrożu. Personalistyczna filozofia wychowania. Kraków: Wydawnictwo UJ.

Bartnik, Cz.S. (2013). Personalizm. Lublin: Wydawnictwo KUL.

Bednarczuk, B. (2016). Osobowość autorska absolwentów klas Montessori w perspektywie doświadczeń i celów życiowych. Lublin: Wydawnictwo UMCS.

Chapliy, N. (2013). Wszechstronny rozwój jednostki w społeczeństwie demokratycznym. Związek teorii dezintegracji pozytywnej Kazimierza Dąbrowskiego w koncepcji Gustawa Radbrucha. Warszawa: Marek Woch.

Chrobak, S. (1999). Personalistyczny wymiar pedagogii Jana Pawła II. W: F. Adamski (red.), Wychowanie na rozdrożu. Personalistyczna filozofia wychowania. Kraków: Wydawnictwo UJ. 
Chrobak, S. (2009). Tożsamość człowieka w pryzmacie nadziei. W: K. Szudry i K. Uzar (red.), Personalistyczny wymiar filozofii wychowania. Lublin: Wydawnictwo KUL.

Chudy, W. (2007). Podstawy filozoficzna pedagogiki samowychowania. Rocznik Nauk Społecznych, t. XXXV, z. 2.

Chudy, W. (2009). Pedagogika godności. Elementy etyki pedagogicznej. Lublin: Towarzystwo Naukowe KUL.

Cisek, S. (2010), Metoda analizy i krytyki piśmiennictwa w nauce o informacji i bibliotekoznawstwie w XXI wieku. Przegląd Biblioteczny, z. 3.

Czerepaniak-Walczak, M. (2006). Pedagogika emancypacyjna. Rozwój świadomości krytycznej człowieka. Gdańsk: GWP

Dabrowski, K. (1979). Dezintegracja pozytywna. Warszawa: PIW.

Gadacz, T. (2005). Wychowanie jako spotkanie osób. W: F. Adamski (red), Wychowanie personalistyczne. Wybór tekstów. Kraków: Wydawnictwo WAM.

Gogacz, M. (1997). Osoba zadaniem pedagogiki. Wykłady bydgoskie. Warszawa.

Góźdź, K. (2008). Personalizm systemowy ks. Czesława Stanisława Bartnika. W: M. Rusecki (red.), Personalizm polski. Lublin: Wydawnictwo KUL.

Grzywak-Kaczyńska, M. (2005). Wychowanie do miłości - miłości trzeba się uczyć. W: F. Adamski (red.), Wychowanie personalistyczne. Wybór tekstów. Kraków: Wydawnictwo WAM.

Horowski, J. (2011). Tomistyczna myśl pedagogiczna w Polsce wobec idei personalizmu. Kwartalnik Pedagogiczny, 2 (220).

Jankowska, M. (2011). Godność osoby w aspekcie rozwoju „ja” i poczucia własnej wartości. W: J. Ławrynowicz i A. Zabołotny (red.), Nauka - Etyka - Wiara. NEW 11. Konferencja Chrześcijańskiego Forum Pracowników Nauki. Dobieszków 23-26 czerwca 2011. Warszawa: Chrześcijańskie Forum Pracowników Nauki.

Kaczmarek, K. i Gadacz, T. (2005). Racje za personalistyczną filozofia wychowania. W: F. Adamski (red), Wychowanie personalistyczne. Wybór tekstów. Kraków: Wydawnictwo WAM.

Kowalczyk, S. (2008). Polski personalizm współczesny. W: M. Rusecki (red.), Personalizm polski. Lublin: Wydawnictwo KUL.

Kozielecki, J. (1998). Człowiek wielowymiarowy. Warszawa: Wydawnictwo Akademickie „Żak”.

Krąpiec, M.A. (1999). Człowiek bytem osobowym. W: F. Adamski (red.), Wychowanie na rozdrożu. Personalistyczna filozofia wychowania. Kraków: Wydawnictwo UJ.

Kunowski, S. (2000). Podstawy współczesnej pedagogiki. Warszawa: Wydawnictwo Salezjańskie.

Łobocki, M. (1978). Samowychowanie podstawowa funkcja heteroedukacji. Zagadnienia Wychowawcze a Zdrowie Psychiczne, nr 1.

Łobocki, M. (2006). Wychowanie moralne w zarysie. Kraków: Oficyna Wydawnicza „Impuls”.

Łobocki, M. (2009). W trosce o wychowanie w szkole. Kraków: Oficyna Wydawnicza „Impuls”.

Majka, J. (2005). Wychowanie chrześcijańskie - wychowaniem personalistycznym. W: F. Adamski (red.), Wychowanie personalistyczne. Wybór tekstów. Kraków: Wydawnictwo WAM.

Matulka, Z. (2005). Wartości u podstaw wychowania personalistycznego. W: F. Adamski (red), Wychowanie personalistyczne. Wybór tekstów. Kraków: Wydawnictwo WAM.

Męczkowska, A. (2006). Podmiot i pedagogika: od oświeceniowej utopii ku pokrytycznej dekonstrukcji. Wrocław: Wydawnictwo Naukowe Dolnośląskiej Szkoły Wyższej.

Molesztak, A. (2009). Współczesny świat wartości a wychowanie. W: M. Nowak, E. Smołka, A. Szudra i K. Uzar (red.), Personalistyczny wymiar filozofii wychowania. Lublin: Wydawnictwo

Mróz, A. (2008). Rozwój osobowy człowieka. Badania w kontekście teorii dezintegracji pozytywnej Kazimierza Dąbrowskiego. Lublin: Towarzystwo Naukowe KUL.

Nowak, M. (2003). Pedagogika personalistyczna. W: A. Kwieciński, B. Śliwerski (red.), Pedagogika. Podręcznik akademicki. T. 1. Warszawa: Wydawnictwo Naukowe PWN. 


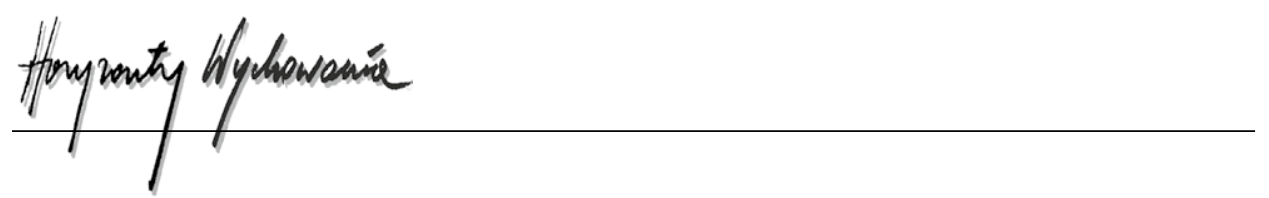

Nowak, M. (2005). Wychowanie do wolności i odpowiedzialności. W: F. Adamski (red.), Wychowanie na rozdrożu. Personalistyczna filozofia wychowania. Kraków: Wydawnictwo UJ.

Obuchowski, K. (1985). Adaptacja twórcza. Warszawa: KiW.

Olbrycht, K. (1999). Dylematy współczesnego wychowania w świetle refleksji personalistycznej. W: F. Adamski (red.), Wychowanie na rozdrożu. Personalistyczna filozofia wychowania. Kraków: Wydawnictwo UJ.

Olbrycht, K. (2005). Tolerancja a wychowanie. W: F. Adamski (red), Wychowanie personalistyczne. Wybór tekstów. Kraków: Wydawnictwo WAM.

Ostrowska, K. (2005). Wychowywać do urzeczywistniania wartości. W: F. Adamski (red), Wychowanie personalistyczne. Wybór tekstów. Kraków: Wydawnictwo WAM.

Rusiecki, M. (2008). Personalizm polski. Lublin: Wydawnictwo KUL.

Rzechowska, E.(1995). Potencjalność w psychologicznej analizie rozwoju. Roczniki Filozoficzne, t. 43, z. 4.

Styczyński, M. (2009). Wspólnota edukacyjne przestrzenią wychowania do wartości. W: M. Nowak, E. Smołka, A. Szudra i K. Uzar (red.), Personalistyczny wymiar filozofii wychowania. Lublin: Wydawnictwo KUL.

Szczepaniak, K. (2012). Zastosowanie analizy treści w badaniach artykułów prasowych - refleksje metodologiczne. Acta Universitatis Lodziensis, Folia Sociologica, 42.

Szołtysek, A. (1999). Nieokreślony podmiot wychowania: pytanie o filozofię człowieka. W: F. Adamski (red.), Wychowanie na rozdrożu. Personalistyczna filozofia wychowania. Kraków: Wydawnictwo UJ.

Szudra A. (2009). Suplement. Dialektyczna etyka wychowania. W: W. Chudy, Pedagogika godności. Elementy etyki pedagogicznej. Lublin: Towarzystwo Naukowe KUL.

Śliwerski, B. (2003). Samowychowanie jako dominanta uniwersyteckiego kształcenia pedagogów. W: A. Ładyżyński i J. Raińczuk (red.), Uniwersytet - między tradycją a wyzwaniami współczesności. Kraków: Oficyna Wydawnicza „Impuls”.

Śnieżyński, M. (2009). Dialog edukacyjny. Kraków: Wydawnictwo Naukowe PAT.

Walczak, P (2009). Pedagogika agatologiczna jako projekt tischnerowskiej paidei. W: K. Szudry i K. Uzar (red.), Personalistyczny wymiar filozofii wychowania. Lublin: Wydawnictwo KUL.

\section{Copyright and License}

This article is published under the terms of the Creative Commons Attribution - NoDerivs (CC BY- ND 4.0) License http://creativecommons.org/licenses/by-nd/4.0/ 